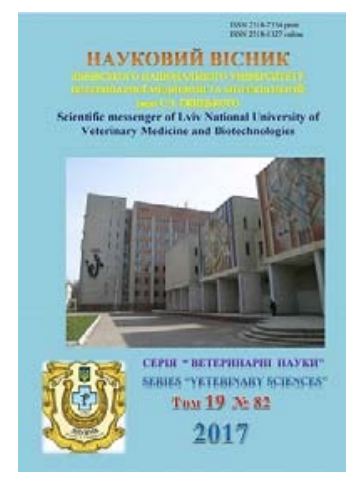

Науковий вісник Львівського національного університету ветеринарної медицини та біотехнологій імені С.З. Гжицького

Scientific Messenger of Lviv National University of Veterinary Medicine and Biotechnologies

doi:10.15421/nvlvet8208

ISSN 2518-7554 print

ISSN 2518-1327 online

$\underline{\text { http://nvlvet.com.ua/ }}$

УДК 619:576 807

\title{
До методики приготування лініменту на основі тіопохідної тріазолу та його оцінка за фізичними властивостями і дією на окремі мікроорганізми та грибки
}

\author{
В.П. Мартинишин ${ }^{1}$, В.М. Гунчак ${ }^{1}$, Б.В. Гутий ${ }^{1}$, О.С. Глух ${ }^{2}$ \\ doctorvetlviv@ukr.net
${ }^{1}$ Львівський національний університет ветеринарної медицини та біотехнологій імені С.3. Гэницкого, вул. Пекарська, 50, Львів, 79010, Украӥна;
${ }^{2}$ Державний вищчий навчальний заклад «Ужсгородський національний університет», \\ вул. Підгірна,46, м. Ужгород, 88000, Украӥна
}

\begin{abstract}
В статті подається методика приготування лініменту за типом олійного розчину на основі тіопохідної тріазолу. 3 метою встановлення ступеня розчинності досліджуваної речовини в олії розторопші плямистої, інших фізичних властивостей (здатність до розшарування, гідрофільність) та протимікробної і протигрибкової дії виготовлялись 1, 3, 5, 7, 10, 12, 15\% кониентрачії лікарської форми. Для приготування нелеткого олійного розчину використовувалася класична технологія із завантаженням розчинника у порядку зростання в'язкості або шільності. У сухі флакони поміщали зважену на аналітичних вагах відповідну наважску діючої субстанції (ПКР-246) і до неї заливали розрахованою масою олію розторопші плямистої. Для забезпечення швидшого розчинення хімічної сполуки в олії флакон нагрівали у водяній бані $\left(40-50{ }^{\circ} \mathrm{C}\right)$. Встановлено, щзо новосинтезована сполука є добре розчинною в олії розторопші в 1,3,5 і 7\% концентрації. Отримані розчини відзначались прозорістю, відсутністю осаду $і$ каламуті. Критичною межею розчинності став 10\% розчин. За помірної розчинності і легкого помутніння для таких розчинів характерною була незначна кристалізачія, що зникала в продовж 10-15 хвилин при нагріванні у водяній бані $\left(18-20^{\circ} \mathrm{C}\right)$. За більш високої концентрації (12 і 15\%) досліджувана хімічна сполука виявилась малорозчинною і нерозчинною, випадала в осад та кристалізувалась. 1, 3, 5 і 7\% конщентрації розчину відзначались стійкістю до розшарування. Для $10 \%$ розчинів досліджуваної лікарської форми характерним було незначне розшарування з ознаками кристалізачії на межі. Сорбуюча здатність олійних розчинів незначна і припинясться через 2 години. 3 о оцінкою впливу новоствореного лікувального засобу на мікроорганізми і грибки відзначено згубний вплив на S. aureus ma C. albicans $i$ A. niger, щңо дає підстави для проведення доклінічних досліджень на лабораторних тваринах саме із 7 i $10 \%$ розчинами такої концентраиії.
\end{abstract}

Ключові слова: тіопохідні тріазолу, лінімент (олійний розчин), олія розторопщі, фізичні властивості, протимікробна $i$ протигрибкова активність.

\section{К методике приготовления линимента на основе тиопохидной триазола и его оценка по физическим свойствам и действию на отдельные микроорганизмы и грибки}

\author{
В.П. Мартинишин ${ }^{1}$, В.М. Гунчак ${ }^{1}$, Б.В. Гутый ${ }^{1}$, О.С. Глух ${ }^{2}$ \\ doctorvetlviv@ukr.net \\ ${ }^{1}$ Львовский национальный университет ветеринарной медицины и биотехнологий имени С.3. Гжсицкого, \\ ул. Пекарская, 50, г. Львов, 79010, Украина; \\ ${ }^{2}$ Государственное высшее учебное заведение «Ужсгородский национальный университет»,
}

Citation:

Martynyshyn, V.P., Gunchak, V.M., Gutyj, B.V., Hlukh, O.S. (2017). To the method of preparation of the liniment on the basis of thiopropyl triazole and his assessment of physical properties and performance on individual microorganisms and fungi. Scientific Messenger LNUVMB, 19(82), 36-40. 
ул. Подгорная, 46, г. Ужгород, 88000, Украина

В статье подается методика приготовления линимента по типу масличного раствора на основе тиопохидной триазола. С иелью установления степени растворимости исследуемого вещества в масле розторопши пятнистой, других физических свойств (способность к расслоению, гидрофильность) и противомикробного и противогрибкового действия изготовлялись 1, 3, 5, 7, 10, 12, 15\% конщентрации врачебной формы. Для приготовления нелетучего масличного раствора использовалась классическая технология с загрузкой растворителя в порядке роста вязкости или плотности. В сухие флаконы помещали взвешенную на аналитических весах соответствующую наважку действующей субстанции (ПКР-246) и к ней заливали рассчитанной массой масло розторопши пятнистой. Для обеспечения более быстрого растворения химического соединения в масле флакон нагревали в водяной бане $\left(40-50{ }^{\circ} \mathrm{C}\right)$. Установлено, что новосинтезированное соединение хорошо растворимо в масле розторопші в 1,3,5 и 7\% конщентрации. Полученные растворы отмечались прозрачностью, отсутствием осадка в мути. Критической гранью растворимости оказался $10 \%$ раствор. При умеренной растворимости и легком помутнении для таких растворов характерной была незначительная кристаллизация, что исчезала на протяжении 10-15 минут при нагревании в водяной бане (18-20 $\left.{ }^{\circ} \mathrm{C}\right)$. При высшей конщентрации (12 и 15\%) исследуемое химическое соединение оказалось малорастворимым и нерастворимым, выпадала в осадок и кристаллизовалась. 1,3,5 и 7\% концентраиия раствору отмечались стойкостью к расслоению. Для $10 \%$ растворов исследуемой врачебной формы характерным было незначительное расслоение с признаками кристаллизации на пределе. Сорбирующая способность масличных растворов незначительна и прекращается через 2 часа. По оченке влияния вновь созданного лечебного средства на микроорганизмы и грибки отмечено губительное влияние на S. aureus и C. albicans i A. niger, что дает основания для проведения доклинических исследований на лабораторных животных именно из 7 и 10\% растворами такой концентрации.

Ключевые слова: тиопохидные триазола, линимент (масляный раствор), масло расторопши, физические свойства, противомикробная и противогрибковая активность.

\title{
To the method of preparation of the liniment on the basis of thiopropyl triazole and his assessment of physical properties and performance on individual microorganisms and fungi
}

\author{
V.P. Martynyshyn ${ }^{1}$, V.M. Gunchak ${ }^{1}$, B.V. Gutyj ${ }^{1}$, O.S. Hlukh ${ }^{2}$ \\ doctorvetlviv@ukr.net
}

\author{
${ }^{I}$ Stepan Gzhytskyi National University of Veterinary Medicine and Biotechnologies Lviv, \\ Pekarska Str., 50, Lviv, 79010, Ukraine; \\ ${ }^{2}$ State Higher Educational Institution «Uzhhorod National University», \\ Pidhirna str., 46, Uzhgorod, 88000, Ukraine
}

\begin{abstract}
The article deals with the method of preparation of the liniment, the type of oil solution, based on thio-derivative of triazole. In order to determine the degree of the solution of the investigating substance in the Saint-Marry-thistle (silybum marianum) oil, other physical properties (capacity to stratification, hydrophilicity) and antimicrobial, antifungal action, the medical forms of the concentration at 1, 3, 5, 7, 10, 12, 15\% were made. For the preparation of non-lethal oil solution,it was used the classical technology with the loading of the solvent in the order of increasing viscosity or density. The active substance weighed on the analytical scales (PCR-246) was put in dry bottles and was filled with the calculated mass of the thistle oil. To provide faster dissolution of the chemical compound in the oil, the vial was heated in a water bath $\left(40-50{ }^{\circ} \mathrm{C}\right)$. It has been established that the new-synthesized compound is well soluble in thistle oil in the forms at 1, 3, 5 and 7\%. The obtained solutions were marked by transparency, lack of sediment in the haze. The critical limit of solubility was $10 \%$ solution. For moderate solubility and light clouding, such crystallization was typical for such solutions, which disappeared in 10-15 minutes on the condition of heating it in a water bath 18$20^{\circ} \mathrm{C}$ ). At higher concentrations (12 and 15\%) the investigated chemical compound was littlesoluble and insoluble, precipitated (felt out in sediment) and crystallized. The concentration of the solution (1, 3, 5 and 7\%) was characterized by resistance to bundle. For $10 \%$ solutions of the investigating dosage form, there was a slight stratification with signs of crystallization on the verge. Sorbent capacity of oil solutions is insignificant and stops after 2 hours. According to the assessment of the effect of the new-developed therapeutic agent on microorganisms and fungi, a deleterious effect on S. aureus and C. albicans and A. niger was noted, which provides the basis for preclinical studies on laboratory animals, especially with the patterns of solution at 7 and $10 \%$ concentration.
\end{abstract}

Key words: triazole, liniment (oil solution), thistle oil, physical properties, antimicrobial and antifungal activity.

\section{Вступ}

Сучасна фармацевтична галузь потребує своєчасного впровадження нових малотоксичних та високоефективних лікарських засобів нового покоління (Obushak et al., 2003; Alekseenko, 2007). Дослідження фармакологічної активності синтетичних органічних сполук, структурним фрагментом у яких є ядра гетероциклічних систем різного походження, свідчать про перспективність подібного пошуку. Відомо, що сполуки, до складу яких входять гетероатоми, виклика- ють великий інтерес у хіміків-синтетиків, фармакологів, дослідників біологічної активності. Нітрогенвмісні сполуки широко поширені в природі та відіграють важливу роль в процесах функціонування живих організмів. Серед синтетичних біологічно активних сполук існує величезна кількість препаратів, які знайшли своє застосування як в медицині, так і у ветеринарії і в сільському господарстві, і за хімічною структурою є гетероциклічними речовинами з атомом Нітрогену. Особливу увагу серед похідних структур привертають похідні 1,2,4-тріазолу (Panasenko, 2005; 
Savchenkova, 2008). Впровадження у лікувальну практику протимікробних засобів з новими фармакологічними властивостями досягається оптимізацією лікування тварин на основі застосування відповідних лікарських форм. Ефективність залежить як від субстанції, що входить до іï складу, так і від розчинника чи основи. За умов зовнішнього використання найбільш широковживаними у практиці ветеринарної медицини є мазі та лініменти (Pertsev et al., 1994). Перевагою останніх $є$ те, що вони не травмують грануляційної тканини, створюють абсолютний контакт 3 рановою поверхнею, в тому числі й за наявності «кишень», нориць чи змертвілих тканин (Panasenko, 2005). Іншими, на нашу думку, є лініменти, що виготовляються за типом розчинів на нелетких розчинниках, зокрема рослинних оліях (Hunchak et al., 2014). Наявні на ринку ветеринарних препаратів протимікробні засоби, в тому числі і у формі мазей та лініментів відзначаються тим, що не завжди стимулюють процеси регенерації тканин. А лікувальні засоби зі здатністю покращувати загоєння ран, зазвичай мають незначні антисептичні властивості (Danko, 2011; Parchenko, 2014). Тому пошук і розробка препаратів, що володіють доброю протимікробною і протигрибковою дією, оскільки часто причиною розвитку патологічних станів у тварин $є$ поєднана контамінація мікроорганізмами і грибками, та проявляли при цьому протизапальну і ранозагоювальну дію, $є$ надзвичайно актуальним питанням сучасної ветеринарної медицини. При створенні нового препарату 3 потенційно вираженою протимікробною і протигрибковою дією нами досліджувалась субстанція на основі тіопохідних тріазолу (умовна назва ПКР-246), синтезовану в лабораторії кафедри токсикологічної та неорганічної хімії Запорізького державного медичного університету (Parchenko et al., 2007). Як розчинник або основа для лініменту було використано олію розторопші плямистої, яка за даними літератури та власних досліджень, є не лише доброю дисперсною системою для діючих речовин, а й самостійно проявляє виражені протизапальні, мембраностабілізувальні та ранозагоювальні властивості (Leng-Perchlow, 1996; Sokol'skaja, 2002). У зв'язку з цим метою нашої роботи було вивчити фізичні властивості (розчинність, стійкість до розшарування, гідрофільність) та протимікробну i протигрибкову активність новосинтезованої субстанції ПКР-246 у формі лініменту.

\section{Матеріал та методи дослідження}

При приготуванні лініменту за типом нелетких олійних розчинів було використано класичну технологію. Її особливістю $\epsilon$ застосування розчинника 3 найкращою розчинюючою для даної речовини здатністю. Нашими дослідженнями було встановлено, що нова синтезована сполука є розчинною в олії розторопші плямистої. Послідовність технологічних операцій щодо виготовлення такого олійного розчину принципово не відрізнялася від методології у водних розчинах. Однак з урахуванням того, що у випадках виготовлення нелетких розчинів розчинники завантажують у порядку зростання їх в'язкості або щільності, нами для приготування розчину ПКР у олії розторопші в сухий флакон поміщалась зважена на аналітичних вагах наважка ПКР і до неї заливали розрахованою масою олію розторопші. Флакон закупорювали i нагрівали на водяній бані $\left(\mathrm{t}^{\circ} 40-50{ }^{\circ} \mathrm{C}\right)$ до повного розчинення наважки досліджуваної речовини. Було враховано, що розчинення хімічних сполук у оліях проходить повільно, тому нагрівання і помішування проводили безпосередньо у флаконі для відпуску. Фільтрування таких розчинів за необхідності проводили в гарячому вигляді. Розрахунок масової частки розчинної речовини проводили за формулою:

$$
\omega=\frac{m p \cdot p}{m p-H y} \times 100 \%
$$

де $m_{\text {p.p. }}$ - маса розчиненої речовини, г;

$m_{\text {р-ну }}-$ маса розчину; $\left(m_{\text {р-ну }}=m_{\text {р.р. }}+m_{\text {р-ка, }}\right.$ де $m_{\text {р-ка }}-$ маса розчинника, г).

3 метою встановлення ступеня розчинності ПКР246 в олії розторопші та інших іiі фізичних властивостей і оцінки заявленої авторами новоствореної субстанції, протимікробної та протигрибкової активності нами було виготовлено наступні концентрації олійних розчинів: 1, 3, 5, 7, 10, 12 і 15\%. Для визначення стійкості експериментальних варіантів розчину до розшарування нами було внесено по 10 мл олійного розчину у пробірки (по 3 пробірки на кожен варіант), зберігали їх за різного температурного режиму при кімнатній температурі $\left(18-20^{\circ} \mathrm{C}\right)$, у сухожарній шафі $\left(50-60^{\circ} \mathrm{C}\right)$ та в холодильнику $\left(2-4{ }^{\circ} \mathrm{C}\right)$. Впродовж 30 діб спостерігали за розшаруванням лініменту в пробірках. Крім того, було проведено дослідження кінетики абсорбції води виготовленими олійними розчинами. Для цього наважки лікарської форми об'ємом 10 мл поміщали у целофанові пакети і переносили їх до склянок з ізотонічним розчином натрію хлориду. Кожну годину пакети діставали з розчину, просушували фільтрувальним папером і зважували на аналітичній вазі. Масу води, що абсорбована лініментами, визначали за різницею між початковою масою та за 1, 2, 3, 4 і 6 годин. Протимікробну та протигрибкову активність діючої речовини у формі лініменту досліджували методом дифузії в агар з використанням луночок.

\section{Результати та їх обговорення}

У результаті проведених досліджень встановлено, що новосинтезована сполука є добре розчинною в олії розторопші у 1, 3, 5 і 7\% концентрації. При цьому отримані розчини відзначались прозорістю, відсутністю осаду і каламуті та були позбавлені кристалізації. Проте критичною межею розчинності стали $10 \%$ розчини. За помірної розчинності і легкого помутніння характерним для такого розчину була незначна кристалізація, що швидко (100-15 хв) зникала при нагріванні у водяній бані $\left(\mathrm{t}^{\circ} 25^{\circ} \mathrm{C}\right)$ (табл. 1).

Дослідженням розчинів більш високої концентрації (12 і 15\%) було встановлено їх нерозчинність, непрозорість і здатність до швидкої кристалізації, що не зникає при нагріванні впродовж тривалого часу 
(1 год). За оцінкою здатності олійних розчинів до розшарування з'ясовано, що досліджувані концентрації $(1,3,5$ і 7\%) лікарської форми впродовж 30 діб розшаруванню не піддаються. Щодо 10\% концентрації, то нами відзначено в пробірках незначне розша- рування 3 ознаками кристалізації вже на 2-3 добу досліджень. За гідрофільністю всі досліджувані олійні розчини в малих кількостях абсорбують воду, причому лише в перші 2 години. Відтак їх сорбуюча здатність припиняється (табл. 2).

Таблиия 1

Оцінка досліджуваного лініменту за фізичними властивостями

\begin{tabular}{|c|c|c|c|}
\hline \multirow{2}{*}{$\begin{array}{c}\text { Концентрація, } \\
\text { \% } \\
\end{array}$} & \multicolumn{3}{|c|}{ Фізичні властивості } \\
\hline & Розчинність & Прозорість & Кристалізація \\
\hline 1 & Розчинний & Так & Немає \\
\hline 3 & Розчинний & Так & Немає \\
\hline 5 & Розчинний & Так & Немає \\
\hline 7 & Розчинний & Так & Немає \\
\hline 10 & Помірно розчинний & Легке помутніння & $\begin{array}{l}\text { Незначна, що зникає при нагріванні у водяній бані } \\
\left(18-20^{\circ} \mathrm{C}\right) \text { впродовж } 10 \text { хвилин }\end{array}$ \\
\hline 12 & Малорозчинний & Стійке помутніння & $\begin{array}{l}\text { Виражена кристалізація, що зникає при нагріванні } \\
\text { повільно }\end{array}$ \\
\hline 15 & Малорозчинний & $\begin{array}{c}\text { Помутніння } \\
\text { з осадом }\end{array}$ & Повна кристалізація, що не зникає при нагріванні \\
\hline
\end{tabular}

Таблиця 2

Оцінка протимікробної та протигрибкової дії лініменту залежно від концентрації лікарської речовини

\begin{tabular}{|c|c|c|c|c|}
\hline \multirow{2}{*}{$\begin{array}{c}\text { Концентрація, } \\
\%\end{array}$} & \multicolumn{4}{|c|}{ Зона затримки росту, мм } \\
\cline { 2 - 5 } & S. aureus & E. coli & C. albicans & A. niger \\
\hline 1 & --- & --- & $2,0-3,0$ & $2,5-3,0$ \\
\hline 3 & $2,0-3,0$ & --- & $7,0-8,0$ & $10,0-11,0$ \\
\hline 5 & $7,8-8,0$ & --- & $14,0-15,0$ & $14,0-15,0$ \\
\hline 7 & $13,8-14,0$ & --- & $14,5-15,0$ & $16,5-17,5$ \\
\hline 10 & $12,8-13,0$ & --- & $15,0-16,0$ & $17,0-18,0$ \\
\hline
\end{tabular}

За оцінкою впливу новоствореного лікарського засобу на мікроорганізми і грибки встановлено, що кращий ефект на $S$. aureus досягається за використання 7 і 10\% концентрації (зона затримки росту мікроорганізмів - 13-14 мм). Однак при цьому на E. coli препарат не діє в жодній досліджуваній концентрації. 3'ясовано, що новостворена субстанція і виготовлена на іiї основі лікарська форма лінімент має кращу дію на грибки. Зокрема встановлено, що за 7 і 10\% концентрації олійних розчинів зона затримки росту мала на C. albicans 14,5-16 мм, а для $A$. niger - 16,5-18 мм. Стосовно інших концентрацій відзначено також достатньо високу протигрибкову активність 5\% лініментів похідної тріазолу. 1 і 3\% олійні розчини в цьому плані виявились менш ефективні.

\section{Висновки}

За результатами проведених досліджень встановлено, що 7 і 10\% лініменти, створені на основі новосинтезованої субстанції ПКР-246 і олії розторопші плямистої, за фізичними властивостями та протигрибковою дією відповідають вимогам до такої лікарської форми і можуть бути використані в подальших дослідженнях.

Перспектива подальших досліджень полягає у дослідженні гострої та хронічної токсичності новоствореної лікарської форми.

\section{Бібліографічні посилання}

Alekseenko, A.L. (2007). Sintez proizvodnyh w-(azol-1il)alkanovyh kislot i izuchenie ih biologicheskoj aktivnosti: dis. kand. him. nauk: 02.00.03. M., 198 (in Russian).

Obushak, N.D., Matijchuk, V.S., Martjak, R.L. (2003). Sintez geterociklov na osnove produktov anionarilirovanija nepredel'nyh soedinenij. Produkty galogenarilirovanija akrilovoj kisloty $\mathrm{i}$ ee jefirov $\mathrm{v}$ sinteze proizvodnyh benzo[b]tiofena. Himija geterociklich. soedinenij. 7, 1019-1026 (in Russian).

Panasenko, O.I. (2005). Syntez, peretvorennia, fizykokhimichni ta biolohichni vlastyvosti pokhidnykh 1,2,4-triazolu: dys. d-ra farm. Nauk. K., 396 (in Ukrainian).

Savchenkova, L.V. (2008). Klinichna farmakolohiia tiotriazolinu: (ohliad lit.). Ukr. med. almanakh. 11(3), 212-217 (in Ukrainian).

Pertsev, I.M., Datsenko, B.M., Hunko, V.H. (1994). Konstruiuvannia likarskykh system bahato spriamovanoi dii u vyhliadi mazei dlia likuvannia infikovanykh ran. Visnyk farmatsii. 1-2, 91-95 (in Ukrainian).

Hunchak, V.M., Danko, H.V., Slobodiuk, N.M., Gutyi, B.V. (2014). Liniment dlia likuvannia tvaryn $z$ hniinonekrotychnymy urazhenniamy shkiry. Patent na korysnu model № 94227; zaiavnyky ta patentovlasnyky Lvivskyi natsionalnyi universytet veterynarnoi medytsyny ta biotekhnolohii imeni S.Z. Hzhytskoho. Zaiavl. 31.03.2014; Opubl. 10.11.2014, Biul. № 21 (in Ukrainian). 
Danko, H.V. (2011). Membranostabilizuvalni vlastyvosti mazi, yaka mistyt oliiu plodiv roztoropshi pliamystoi. Naukovo-tekhnichnyi biuleten instytutu biolohii tvaryn, DNDKI vetpreparativ ta kormovykh dobavok. 12(3-4), 176-180 (in Ukrainian).

Parchenko, V.V. (2014). Syntez, peretvorennia, fizykokhimichni ta biolohichni vlastyvosti v riadu 5-furylzamishchenykh 1,2,4-triazol-3-tioniv: dys. - doktor farmatsevtychnykh nauk. Zaporizhzhia, 361 (in Ukrainian).

Parchenko, V.V., Panasenko, O.I., Knysh, Ye.H. (2007). Fizyko-khimichni vlastyvosti ta hostra toksychnist pokhidnykh
Farmatsevtychnyi chasopys. 2(2), 41-43 (in Ukrainian).

Sokol'skaja, T.A. (2002). Sozdanie lekarstvennyh sredstv iz plodov rastoropshi pjatnistoj (poluchenie, standartizacija i kontrol' kachestva). Farmacija. 1, 32 (in Russian).

Leng-Perchlow, E. (1996). Properties and medical use of flavolignans (silymarin) from silybum mariarum. Phytother. Res. 10, 25-26.

Received 21.09.2017

Received in revised form 25.10.2017

Accepted 30.10.2017 